\title{
Effect of dietary conjugated linoleic acid on body composition and energy balance in broiler chickens
}

\author{
Marjan Javadi ${ }^{1}$, Math J.H. Geelen ${ }^{1} *$, Henk Everts ${ }^{1}$, Robert Hovenier ${ }^{1}$, Shahram Javadi ${ }^{2}$, Henk Kappert ${ }^{1}$ \\ and Anton C. Beynen ${ }^{1}$ \\ ${ }^{1}$ Department of Nutrition, Faculty of Veterinary Medicine, Utrecht University, Yalelaan 104 P.O. Box 80.152, 3508 TD Utrecht, \\ The Netherlands \\ ${ }^{2}$ Department of Clinical Sciences of Companion Animals, Faculty of Veterinary Medicine, Yalelaan 108, P.O. Box 80.154, 3508 TD \\ Utrecht, The Netherlands
}

(Received 12 January 2007 - Revised 27 April 2007 - Accepted 30 April 2007)

The effect of dietary conjugated linoleic acid (CLA) on body composition and energy metabolism was investigated in broiler chickens. Male broiler chicks were assigned to receive either a control diet (1\% sunflower oil) or a diet containing CLA (1\% of a 1:1 mixture of trans-10, cis-12 and cis-9, trans-11 isomers of octadecadienoic acid). The diets were fed ad libitum for 3 weeks and there were eight replicates per diet, each replicate including four chickens so that each treatment had thirty-two animals. The proportion of body fat was lower in the control group than in the CLA group. No significant differences as to the proportions of body water, ash and protein were observed. Feed and energy intake were significantly lower in CLA-fed birds. The percentage of ingested energy lost in excreta was higher after CLA feeding and heat expenditure as a percentage of ingested energy was lower in the CLA-fed group. The CLA-fed group showed a higher percentage of SFA and lower percentages of MUFA and PUFA in carcass fat. It is concluded that CLA stimulated de novo fatty acid synthesis and lowered desaturase activity.

Conjugated linoleic acid: Body composition: Energy metabolism: Broilers

The term conjugated linoleic acid (CLA) is used to designate a mixture of positional and geometric isomers of linoleic acid in which the double bonds are conjugated. Considerable attention has been paid to the potential, beneficial health effects of dietary CLA. CLA was found to act as a growth factor ${ }^{1}$, as a fat-to-lean repartitioning agent ${ }^{2-7}$, and it has anticarcinogenic ${ }^{8,9}$, hypocholesterolaemic and antiatherogenic ${ }^{10,11}$ properties. Food intake is usually not affected by incorporation of CLA in the diets and, therefore, the body fat-lowering effect of CLA is most likely mediated by enhanced energy expenditure. Measuring the energy expenditure of mice in metabolic chambers fed CLA indeed demonstrated an increase of energy expenditure ${ }^{12}$.

Szymczyk et al. ${ }^{13}$ showed that feeding CLA to broiler chickens resulted in subtantial incorporaton of CLA isomers into their tissue lipids, thus providing a potential CLA-rich source for human consumption. In their study, feeding CLA significantly decreased feed intake during the starter (8-21 d) period, but no effect was noted during the growerfinisher $(22-42 \mathrm{~d})$ period. Abdominal fat deposition was significantly reduced whereas the relative proportion of breast muscles was unaffected and that of leg muscles significantly increased $^{13}$. It could be suggested that CLA feeding influences body composition and energy metabolism of broiler chickens.

The objective of the present study was to test whether the earlier observed CLA-induced reduction of abdominal fat in chickens ${ }^{13}$ is associated with enhanced energy expenditure by investigating the influence of dietary CLA on growth, body composition and energy balance in broilers. In addition, the fatty acid composition of total carcass lipid was evaluated.

\section{Experimental methods}

The experimental protocol was approved by the animal experiments committee of the Faculty of Veterinary Medicine, Utrecht University, The Netherlands.

\section{Animals and diets}

One-day-old male broiler chickens (Ross 308) were purchased from a local hatchery. On arrival, they were wing-banded, weighed and housed in wire-floored, suspended cages. The temperature of the animal house was controlled and continuous lighting used throughout the entire experimental period. There were two dietary treatments, each consisting of eight replicates. A replicate was identical to a cage with four birds so that each treatment had thirty-two animals. Ten birds were killed at the beginning of the study to determine pre-experimental body composition. Sixty-four broilers were used for the feeding trial. The base diet was in pelleted form (Table 1) and fed for $7 \mathrm{~d}$. To produce the experimental 
Table 3. Body composition and energy balance in broiler chickens fed the control diet or a conjugated linoleic acid (CLA)-containing diet for $21 \mathrm{~d}$

(Mean values with their standard errors for eight units with each unit including four birds)

\begin{tabular}{|c|c|c|c|c|c|c|}
\hline \multirow[b]{2}{*}{ Parameter } & \multicolumn{2}{|c|}{ CLA } & \multicolumn{2}{|c|}{ Control } & \multirow[b]{2}{*}{ SEM (pooled) } & \multirow[b]{2}{*}{$P$ value } \\
\hline & Mean & SE & Mean & SE & & \\
\hline Feed intake $(g / 21 d)$ & 1769 & 81.5 & 1897 & $149 \cdot 1$ & $42 \cdot 4$ & 0.051 \\
\hline Feed conversion (g feed/g weight gain) & 1.44 & 0.033 & 1.48 & 0.078 & 0.02 & 0.133 \\
\hline Initial body weight $(\mathrm{g})$ & $144 \cdot 3$ & 7.5 & $140 \cdot 4$ & $9 \cdot 4$ & 3.0 & 0.372 \\
\hline Final body weight $(\mathrm{g})$ & 1376 & $62 \cdot 0$ & 1418 & $57 \cdot 7$ & $21 \cdot 2$ & 0.191 \\
\hline Weight gain in $21 \mathrm{~d}(\mathrm{~g})$ & 1232 & $63 \cdot 4$ & 1277 & $56 \cdot 5$ & $21 \cdot 2$ & 0.156 \\
\hline Apparent fat digestibility (\%) & 75.93 & 3.43 & $79 \cdot 65$ & 2.44 & 1.05 & 0.026 \\
\hline Energy metabolisability (\%) & $72 \cdot 57$ & $2 \cdot 19$ & $75 \cdot 70$ & $1 \cdot 17$ & 0.62 & 0.003 \\
\hline \multicolumn{7}{|l|}{ Body composition after $21 \mathrm{~d}$} \\
\hline Fat $(\mathrm{g})$ & $161 \cdot 71$ & $13 \cdot 27$ & $152 \cdot 2$ & $13 \cdot 16$ & $4 \cdot 67$ & 0.171 \\
\hline Water (g) & 923 & 58.5 & 962 & $47 \cdot 3$ & $18 \cdot 8$ & 0.166 \\
\hline Protein (g) & $237 \cdot 0$ & $11 \cdot 72$ & $241 \cdot 7$ & $10 \cdot 65$ & 3.96 & 0.415 \\
\hline Ash $(g)$ & 32.99 & 3.998 & $36 \cdot 33$ & 3.906 & 1.40 & 0.114 \\
\hline Fat $(\%)$ & $11 \cdot 76$ & 1.07 & $10 \cdot 73$ & 0.78 & 0.33 & 0.044 \\
\hline Water (\%) & 67.03 & 1.67 & $67 \cdot 86$ & 1.07 & 0.50 & 0.258 \\
\hline Protein (\%) & $17 \cdot 24$ & 1.07 & $17 \cdot 05$ & 0.30 & 0.28 & 0.634 \\
\hline Ash (\%) & 2.41 & 0.35 & 2.57 & 0.30 & 0.12 & 0.345 \\
\hline \multicolumn{7}{|l|}{ Deposition in body } \\
\hline Fat $(g / 21 d)$ & $150 \cdot 9$ & $13 \cdot 26$ & $141 \cdot 6$ & $13 \cdot 16$ & $4 \cdot 67$ & 0.183 \\
\hline Water (g/21 d) & 815 & 58.96 & 856 & $47 \cdot 96$ & $19 \cdot 0$ & 0.141 \\
\hline Protein (g/21 d) & $218 \cdot 6$ & $12 \cdot 12$ & $223 \cdot 8$ & $10 \cdot 38$ & $4 \cdot 01$ & 0.375 \\
\hline Ash $(g / 21 d)$ & $30 \cdot 10$ & 3.995 & 33.51 & 3.846 & 1.39 & 0.104 \\
\hline Energy (kJ/21 d) & 11186 & $750 \cdot 6$ & 10941 & $675 \cdot 0$ & $252 \cdot 4$ & 0.504 \\
\hline \multicolumn{7}{|l|}{ Energy balance } \\
\hline Intake $(\mathrm{MJ} / 21 \mathrm{~d})$ & $30 \cdot 06$ & $1 \cdot 37$ & $32 \cdot 22$ & $2 \cdot 53$ & 1.02 & 0.052 \\
\hline Retained in body (MJ/21 d) & $11 \cdot 18$ & 0.75 & 10.94 & 0.67 & 0.25 & 0.504 \\
\hline Excreta $(\mathrm{MJ} / 21 \mathrm{~d})$ & $8 \cdot 23$ & 0.557 & $7 \cdot 83$ & 0.654 & 0.22 & 0.204 \\
\hline Heat production (MJ/21 d) & $10 \cdot 65$ & $1 \cdot 25$ & 13.46 & 1.68 & 0.52 & 0.002 \\
\hline
\end{tabular}

\section{Energy balance}

Energy intake was lower in CLA-fed birds, lowering almost reaching statistical significance (Table 3). Apparent fat digestibility and energy metabolisability were higher in the control group $(P=0.026$ and 0.003 , respectively). Energy expenditure was calculated as the difference between the energy intake and the energy stored and excreted in the excreta. The higher heat production calculated for the control group differed from that for the CLA group $(P=0 \cdot 002)$. Energy storage was not affected by CLA feeding. The proportion of energy intake that was stored in the body was lower in controls than in the CLA-fed group (0.34 (SEM 0.02) and 0.37 (SEM 0.02), respectively; $P=0 \cdot 007$ ).

\section{Feed and carcass fatty acid composition and feed efficiency}

As CLA was added to the experimental diet at the expense of sunflower oil, the ingested amounts of SFA, MUFA, PUFA- $n$ 6 and PUFA- $n-3$ dropped (Table 4 ). The amounts of fatty acid

Table 4. Selected fatty acids as ingested in broiler chickens fed a control or a conjugated linoleic acid (CLA)-containing diet for a period of $21 \mathrm{~d}(\mathrm{~g} / 21 \mathrm{~d})$

(Mean values with their standard errors for eight units with each unit including four birds)

\begin{tabular}{|c|c|c|c|c|c|c|}
\hline \multirow[b]{2}{*}{ Fatty acid† } & \multicolumn{2}{|c|}{ CLA } & \multicolumn{2}{|c|}{ Control } & \multirow[b]{2}{*}{ SEM } & \multirow[b]{2}{*}{$P$ value } \\
\hline & Mean & SE & Mean & SE & & \\
\hline C16: 0 & $14 \cdot 69$ & 0.673 & 16.46 & $1 \cdot 294$ & 0.4 & 0.006 \\
\hline C18: 0 & 4.01 & 0.1827 & $4 \cdot 876$ & 0.3832 & $0 \cdot 1$ & $<0.001$ \\
\hline C18: $1 n-9$ & $23 \cdot 48$ & 1.069 & $29 \cdot 02$ & $2 \cdot 281$ & 0.63 & $<0.001$ \\
\hline C18: $2 n-6$ & $54 \cdot 2$ & 2.466 & $70 \cdot 4$ & $5 \cdot 53$ & 1.51 & $<0.001$ \\
\hline C18: $3 n-3$ & $5 \cdot 305$ & 0.2415 & $5 \cdot 808$ & 0.4565 & 0.1291 & 0.016 \\
\hline$\Sigma$ SFA & $20 \cdot 48$ & 0.932 & $23 \cdot 39$ & $1 \cdot 838$ & 0.515 & 0.001 \\
\hline$\Sigma$ MUFA & $25 \cdot 86$ & $1 \cdot 177$ & 31.61 & $2 \cdot 484$ & 0.687 & $<0.001$ \\
\hline$\Sigma$ PUFA- $n-6$ & $54 \cdot 26$ & 2.469 & $70 \cdot 45$ & 5.537 & 1.52 & $<0.001$ \\
\hline$\Sigma$ PUFA- $n-3$ & $6 \cdot 36$ & 0.289 & 6.95 & 0.5466 & 0.155 & 0.017 \\
\hline$\Sigma C L A$ & $11 \cdot 398$ & 0.519 & - & & & \\
\hline ¿PUFA total & $60 \cdot 62$ & $2 \cdot 759$ & $77 \cdot 40$ & 6.083 & 1.67 & 0.001 \\
\hline
\end{tabular}

†Total fatty acid contents were calculated as follows: total fat measured $\times 0.95 \times$ percentage of selected fatty acid. 
Table 5. Selected fatty acids stored in the body of broiler chickens fed a control or a conjugated linoleic acid (CLA)-containing diet for a period of $21 \mathrm{~d}(\mathrm{~g} / 21 \mathrm{~d})$

(Mean values with their standard errors for eight units with each unit including four birds)

\begin{tabular}{|c|c|c|c|c|c|c|}
\hline \multirow[b]{2}{*}{ Fatty acid† } & \multicolumn{2}{|c|}{ CLA } & \multicolumn{2}{|c|}{ Control } & \multirow[b]{2}{*}{ SEM } & \multirow[b]{2}{*}{$P$ value } \\
\hline & Mean & SE & Mean & $\mathrm{SE}$ & & \\
\hline C16: 0 & 42.48 & 3.33 & 24.91 & 2.96 & $1 \cdot 10$ & $<0.001$ \\
\hline C18: 0 & 19.62 & 1.57 & $8 \cdot 36$ & 0.54 & 0.40 & $<0.001$ \\
\hline C18: $1 n-9$ & $36 \cdot 37$ & 3.23 & $45 \cdot 19$ & 5.80 & 1.66 & 0.002 \\
\hline$\Sigma$ SFA & 64.52 & 4.99 & 34.73 & 3.42 & 1.51 & $<0.001$ \\
\hline ¿MUFA & 43.01 & 3.89 & 53.23 & $7 \cdot 17$ & 2.04 & 0.003 \\
\hline$\Sigma$ PUFA- $n-6$ & $26 \cdot 33$ & 9.45 & 41.26 & $2 \cdot 62$ & 2.45 & $<0.001$ \\
\hline$\Sigma$ PUFA- $n-3$ & $2 \cdot 20$ & 1.06 & $3 \cdot 36$ & 0.25 & 0.27 & $0.00 s$ \\
\hline$\Sigma \mathrm{CLA}$ & $2 \cdot 70$ & 1.53 & 0 & 0 & 0.38 & $<0.001$ \\
\hline ¿PUFA total & 28.53 & $10 \cdot 50$ & 44.61 & $2 \cdot 83$ & $2 \cdot 72$ & $<0.001$ \\
\hline
\end{tabular}

$\dagger$ Total fatty acid contents were calculated as follows: total fat measured $\times 0.95$ $\times$ percentage of selected fatty acid.

stored in the carcasses are shown in Table 5. The amount of SFA in carcasses was increased in the CLA-fed group $(P<0.001)$ and the amount of MUFA and PUFA were decreased $(P=0.003$ and $P<0 \cdot 001$, respectively).

CLA consumption markedly increased the efficiency of incorporation (fatty acid deposited/fatty acid ingested) of SFA and decreased the incorporation of PUFA- $n-3$ (Table 6). Taking into account the amounts of fatty acids in the body at the start of the experiment, the ingested amounts of fatty acids and the amounts of fatty acids at the end of the experiment, one can estimate the minimal rate of de novo fatty acid synthesis during $21 \mathrm{~d}$ or the maximal rate of fatty acid degradation/disappearance in that period. The data indicated that CLA feeding preferentially induced SFA synthesis and that degradation/disappearance of PUFA is unaffected (Table 6).

\section{Discussion}

The effect of CLA on body composition and energy expenditure was studied in broiler chickens fed $1 \mathrm{~g} \mathrm{CLA} / 100 \mathrm{~g}$ diet. CLA feeding depressed feed intake, fat digestibility and energy metabolisability. This must result in a lower amount of metabolisable energy in the CLA treated group. However, weight gain during the experimental period did not differ between the dietary treatments. Moreover, deposition of fat, water, protein, ash and energy was not different (Table 3). CLA feeding had no negative effect on body fat deposition. Feed conversion was non-significantly lower in the CLA-fed birds, which is consistent with the finding by Szymczyk et $a{ }^{13}{ }^{13}$. The fat proportion, however, was higher in the body of birds fed CLA when compared to controls. This result is consistent with the finding by $\mathrm{Du} \& \mathrm{Ahn}^{19}$ who found that feeding a diet containing $0.5 \%$ CLA to broilers at 3 weeks of age, for a period of 3 weeks, resulted in an increase in abdominal fat content. Several studies have shown that incorporation of $1 \%$ or less CLA in the diet can substantially reduce the proportion of body fat in mice $7,12,20$, rats $^{21,22}$, chickens ${ }^{13}$ and $\operatorname{man}^{23,24}$. The effects in mice appear more striking than in other species ${ }^{25}$. Badinga et $a .^{26}$ found that feeding CLA at the level of $5 \%$ to $1-\mathrm{d}$ old broiler chickens for a period of $21 \mathrm{~d}$ significantly lowered the proportion of body fat and increased the proportion of body water. Szymczyk et al. ${ }^{13}$ found lower abdominal fat in the body when they fed birds a diet with $1 \%$ CLA. As mentioned earlier, Du \& $\mathrm{Ahn}^{19}$ observed an increase in abdominal fat in broilers fed CLA. Thus, experimental conditions such as age, genotype and metabolic status of the animal, as well as the level, the type of isomer and duration of CLA treatment may play an integral role in how CLA affects body composition. The lack of agreement between previous works suggests mechanisms involved are complicated and multiple.

Table 6. Minimum rate of de novo fatty acid synthesis, maximum rate of fatty acid disappearance and efficiency of incorporation of selected fatty acids in the body of broiler chickens fed a control diet or a conjugated linoleic acid (CLA)-containing diet for a period of $21 \mathrm{~d}$

(Mean values for eight determinations per treatment group)

\begin{tabular}{|c|c|c|c|c|c|c|}
\hline Fatty acid & Diet & Intake $(g / 21 d)$ & Retained (g/21 d) & Efficiency† & Minimum synthesis $\ddagger$ (g/21 d) & Maximum disappearance $\S(\mathrm{g} / 21 \mathrm{~d})$ \\
\hline \multirow[t]{2}{*}{ C16: 0} & CLA & $14 \cdot 7^{\star \star}$ & $42 \cdot 5^{\star \star \star}$ & $2 \cdot 87^{\star \star *}$ & $27 \cdot 8^{\star \star \star}$ & \\
\hline & Control & $16 \cdot 5$ & $24 \cdot 9$ & 1.52 & 8.4 & \\
\hline C18: 0 & Control & 4.9 & 8.4 & 1.72 & 3.5 & \\
\hline \multirow[t]{2}{*}{ C18: $1 n-9$} & CLA & $23 \cdot 5^{\star \star \star}$ & $36 \cdot 4^{\star \star}$ & 1.55 & $12 \cdot 9$ & \\
\hline & Control & $29 \cdot 0$ & $45 \cdot 2$ & 1.56 & $16 \cdot 2$ & \\
\hline$\Sigma$ SFA & CLA & $20 \cdot 5^{\star \star \star}$ & $64 \cdot 5^{\star \star \star}$ & $3 \cdot 15^{\star \star \star}$ & $44 \cdot 0^{\star \star \star}$ & \\
\hline \multirow[t]{2}{*}{ ¿MUFA } & CLA & $25 \cdot 9^{\star \star \star}$ & $43 \cdot 0^{\star *}$ & $1 \cdot 66$ & $17 \cdot 1$ & \\
\hline & Control & 31.6 & $53 \cdot 2$ & 1.68 & $21 \cdot 6$ & \\
\hline \multirow[t]{2}{*}{$\Sigma$ PUFA- $n-6$} & CLA & $54 \cdot 3^{\star \star \star}$ & $26 \cdot 3^{\star \star \star}$ & 0.48 & & $28 \cdot 0$ \\
\hline & Control & 70.5 & $41 \cdot 3$ & 0.59 & & $29 \cdot 2$ \\
\hline \multirow[t]{2}{*}{$\Sigma$ PUFA- $n-3$} & CLA & $6 \cdot 40^{\star}$ & $2 \cdot 2^{\star \star}$ & $0.35^{\star}$ & & $4 \cdot 2$ \\
\hline & Control & 6.95 & 3.4 & 0.48 & & $3 \cdot 6$ \\
\hline \multirow[t]{2}{*}{$\Sigma$ PUFA total } & CLA & $60 \cdot 6^{\star \star \star}$ & $28 \cdot 5^{\star \star \star}$ & 0.47 & & $32 \cdot 1$ \\
\hline & Control & $77 \cdot 4$ & $44 \cdot 6$ & 0.58 & & $32 \cdot 8$ \\
\hline
\end{tabular}

Mean values were significantly different from those of the control diet: ${ }^{\star} P<0.05,{ }^{* \star} P<0.01,{ }^{\star * \star} P<0.001$

$\dagger$ Efficiency is expressed as the ratio of fatty acid deposited in the body and dietary fatty acid.

$\ddagger$ The values for the minimum amount of fatty acid synthesised are obtained by subtracting the amount of intake from the amount of retained.

$\S$ The values for the maximum amount of fatty acid disappearing are obtained by subtracting the amount of retained from the amount of intake. 
Much to our surprise, the energy balance indicated that the calculated heat production was about $20 \%$ lower in CLA-fed birds compared to the controls. This is opposite to what happens in mice after CLA consumption ${ }^{7}$. The present study does not give any information on the mechanism responsible for the decrease in energy expenditure in broilers fed CLA. However, it is tempting to speculate that the decrease in energy expenditure is related to the increase in the proportion of body fat. Another possibility is an effect of CLA on non-shivering thermogenesis, which is quite different in birds as compared to mammals where brown adipose tissue is the site for nonshivering thermogenesis. Birds lack brown adipose tissue ${ }^{27}$.

Lee et $a l^{28}$ observed that CLA has the ability to alter the fatty acid composition of tissues by reducing the levels of MUFA which is consistent with the present findings. Choi et $a ._{.}{ }^{29}$ observed that the ratio of SFA to MUFA in mice fed CLA was increased and indicated that this was related to a lipid-lowering effect of CLA. Studies in rats ${ }^{30,31}$ and chickens ${ }^{13,32}$ have shown that the percentage of SFA in the body increases whereas those of MUFA and PUFA decrease. The same was true for egg yolks of eggs produced by hens fed $\mathrm{CLA}^{33,34}$. In the present study, we also found a marked increase in SFA, but no lipid-lowering effect of CLA was observed. Carcasses of rats fed CLA also contained a higher proportion of SFA and less $\mathrm{PUFA}^{35}$. The reduction in MUFA (oleic acid) may be the result of a reduced $\Delta-9$ desaturase activity due to feeding CLA $^{36-38}$. The arachidonic acid concentration decreased in the carcasses. The present results are consistent with those of Belury \& Kempa-Steczko ${ }^{39}$ who proposed that CLA, acting as a substrate for $\Delta-6$ desaturase, inhibited the conversion of linoleic acid into arachidonic acid. Consistent with the present observations is the finding that CLA dramatically reduced the percentages of MUFA in all tissues investigated through inhibition of $\Delta-9$ desaturase $^{29,36,40,41}$. The trans-10, cis-12 CLA isomer has been shown to have the highest biological activity in this respect, whereas cis-9, trans-11 CLA does not reduce the activity of $\Delta-9$ desaturase ${ }^{40,42}$.

The changes in fatty acid composition greatly increase the melting point for fat retained in the CLA-fed group (from 21 to around $35^{\circ} \mathrm{C}$ ). What kind of effects this will trigger in the broilers is unknown yet. A similar change in fatty acid composition results in complete loss of hatchability of eggs from CLA-fed chickens ${ }^{33,34}$. In the broilers such a change in fatty acid composition makes chicken meat harder and drier ${ }^{19}$.

When we calculate the amounts of fatty acids stored in the body during the experimental period and also the amounts of fatty acids ingested, we can determine the efficiency of fatty acid incorporation into the body. Calculation revealed a dramatically higher efficiency for SFA and a lower efficiency for PUFA- $n-3$ (Table 6). The CLA-induced differences in efficiency of incorporation might be related to preferential effects on synthesis or degradation of certain fatty acids. If the incorporation ratio was higher than $1 \cdot 0$, then the minimum amount of de novo synthesis of a specific fatty acid was calculated as deposited amount $(\mathrm{g} / 21 \mathrm{~d})$ minus the ingested amount $(\mathrm{g} / 21 \mathrm{~d})$. If the incorporation ratio was lower than $1 \cdot 0$, then the maximum amount of oxidation (or degradation) of a specific fatty acid was calculated as the ingested amount $(\mathrm{g} / 21 \mathrm{~d})$ minus the deposited amount $(\mathrm{g} / 21 \mathrm{~d})$. Both calculations can only indicate the lower and upper limit, respectively, because actual information about digestibility of individual fatty acids and the efficiency of incorporation of dietary fatty acids in deposited fatty acids is not available in the present experiment. The calculations show that CLA feeding preferentially induced SFA synthesis. This may explain the CLA-induced increase in body fat, which was statistically significant when expressed as percentage of the body. Much to our surprise the oxidation of PUFA was unaffected. This is contrary to many observations indicating preferential oxidation of PUFA $^{39,43,44}$. In contrast, some studies have shown that CLA may have a modest enhancing effect on the level of PUFA $^{45,46}$. Yet other studies, like the present one, show no effect of CLA on PUFA levels ${ }^{31,47-49}$. It appears that the ability of CLA to alter PUFA levels is tissue and species dependent. Consistent with the present results on fatty acid synthesis and degradation are our earlier observations showing CLA-induced activity of the lipogenic pathway in mice as evidenced by enhanced activities of acetyl-CoA carboxylase and fatty acid synthase ${ }^{50}$. In that same study it was shown that CLA did not alter the activities of 3-hydroxy-acyl-CoA dehydrogenase and citrate synthase, suggesting that fatty acid oxidation was not affected by CLA feeding ${ }^{50}$.

It might be argued that differences in fatty acid composition between the control and CLA-containing diet may have caused differences in fatty acid deposition. There are indeed differences in fatty acid intake between the two experimental diets, as can be seen from Table 2 with the analysed fatty acid composition of the experimental diets. These differences are due to the fact that CLA was added at the expense of sunflower oil. The differences are minor except for linoleic acid. However, earlier work ${ }^{14}$ indicates that the difference in linoleic acid intake cannot have caused the diet effects observed in the present study. The difference in ingested fatty acids as calculated in Table 4 is mainly caused by the difference in feed intake between the treatments.

Several studies have shown that the specific mechanisms by which dietary CLA reduces the body fat content are likely to vary from one animal species to another. Whether reduced accumulation of liver lipid in broilers fed CLA as observed by Badinga et al. ${ }^{26}$ reflected enhanced $\beta$-oxidation or reduced de novo lipid synthesis warrants further investigation, but the present observation indicates higher de novo synthesis and lower desaturase activity. Measurement of enzyme expression and/or activity would complement the present data.

\section{Acknowledgements}

This study was supported in part by the Stichting Toxicologisch Onderzoek Utrecht. The CLA used in this research was supplied by Loders Croklaan b.v, Wormerveer, The Netherlands. The technical assistance of Jan van der Kuilen is gratefully acknowledged.

\section{References}

1. Chin SF, Storkson JM, Albright KJ, Cook ME \& Pariza MW (1994) Conjugated linoleic acid is a growth factor for rats as shown by enhanced weight gain and improved feed efficiency. J Nutr 124, 2344-2349. 
2. Pariza M, Park Y, Cook M, Albright K \& Liu W (1996) Conjugated linoleic acid (CLA) reduces body fat. FASEB J 10, A560, Abstract 3227.

3. Park Y, Albright KJ, Liu W, Storkson JM, Cook ME \& Pariza MW (1997) Effect of conjugated linoleic acid on body composition in mice. Lipids 32, 853-858.

4. West DB, Delany JP, Camet PM, Blohm F, Truett AA \& Scimeca J (1998) Effect of conjugated linoleic acid on body fat and energy metabolism in the mouse. Am J Physiol 275, R667-R672.

5. Ostrowska E, Muralitharan M, Cross RF, Bauman DE \& Dunshea FR (1999) Dietary conjugated linoleic acids increase lean tissue and decrease fat deposition in growing pigs. $J$ Nutr 129, 2037-2042.

6. Tsuboyama-Kasaoka N, Takahashi M, Tanemura K, Kim H-J, Tange T, Okuyama H, Kasai M, Ikemoto S \& Ezaki O (2000) Conjugated linoleic acid supplementation reduces adipose tissue by apoptosis and develops lipodystrophy in mice. Diabetes 49, 1534-1542.

7. Terpstra AHM, Beynen AC, Everts H, Kocsis S, Katan MB \& Zock PL (2002) The decrease in body fat in mice fed conjugated linoleic acid is due to increases in energy expenditure and energy loss in the excreta. $J$ Nutr 132, 940-945.

8. Schulz TD, Chew BP, Seaman WR \& Luedecke LO (1992) Inhibitory effect of conjugated dienoic derivatives of linoleic acid and beta-carotene on the in vitro growth of human cancer cells. Cancer Lett 63, 125-133.

9. Ip C (1997) Review of the effects of trans fatty acids, oleic acid, n-3 polyunsaturated fatty acids and conjugated linoleic acid on mammary carcinogenesis in animals. Am J Clin Nutr 66, $15235-15295$.

10. Lee KN, Kritchevsky D \& Pariza MW (1994) Conjugated linoleic acid and atherosclerosis in rabbits. Atherosclerosis 108, $19-25$.

11. Nicolosi R, Rogers E, Kritchevsky D, Scimeca J \& Huth P (1997) Dietary conjugated linoleic acid reduces plasma lipoproteins and early aortic atherosclerosis in hypercholesterolemic hamsters. Artery 22, 266-277.

12. West DB, Truett AA, Delany JP \& Scimeca J (2000) Effect of conjugated linoleic acid on body fat and energy metabolism in the mouse. Am J Physiol 275, R667-R672.

13. Szymczyk B, Pisulewski PM, Szczurek W \& Hanczakowski P (2000) The effects of feeding conjugated linoleic acid (CLA) on rat growth performance, serum lipoproteins and subsequent lipid composition of selected rat tissues. J Sci Food Agric 80, $1553-1558$

14. Javadi M, Everts H, Hovenier R, Kocksis S, Lankhorst Æ, Lemmens AG, Schonewille JT, Terpstra AHM \& Beynen AC (2004) The effect of six different $\mathrm{C} 18$ fatty acids on energy metabolism in mice. Br J Nutr 92, 391-399.

15. Metcalfe LD, Schmitz AA \& Pelka JR (1966) Rapid preparation of fatty acid esters from lipids for gas chromatographic analysis. Anal Chem 38, 514-515.

16. Dutch Normalization Institute Methods of Analysis for Feeding Stuffs. Determination of Crude Protein. NEN 3145. Dutch Normalization Institute

17. Dutch Normalization Institute Methods of Analysis for Feeding Stuffs. Determination of Crude Ash. NEN 3329. Dutch Normalization Institute

18. McLean JA \& Tobin G (1987) Animal and Human Calorimetry. Cambridge: Cambridge University Press.

19. Du M \& Ahn DU (2002) Effect of dietary conjugated linoleic acid on the growth rate of live birds and on the abdominal fat content and quality of broiler meat. Poult Sci 81, 428-433.

20. Delany JP, Blohm F, Truett AA, Scimeca JA \& West DB (1999) Conjugated linoleic acid rapidly reduces body fat content in mice without affecting energy intake. Am $J$ Physiol 276, R1172-R1179.

21. Rahman SM, Wang Y-M, Yotsumoto H, Cha J-Y, Han S-Y, Inoue S \& Yanagita T (2001) Effects of conjugated linoleic acid on serum leptin concentration, body-fat accumulation, and $\beta$-oxidation of fatty acids in OLETF rats. Nutrition $\mathbf{1 7}$, $385-390$.

22. Koba K, Akahoshi A, Yamasaki M, Tanaka K, Yamada K, Iwata T, Kamegai K, Tsutsumi K \& Sugano M (2002) Dietary conjugated linolenic acid in relation to CLA differently modifies body fat mass and serum and liver lipid levels in rats. Lipids 37, 243-250.

23. Basu S, Riserus U, Turpeinen A \& Vessby B (2000) Conjugated linoleic acid induces lipid peroxidation in men with abdominal obesity. Clin Sci 99, 511-516.

24. Blankson H, Stakkestad JA, Fagertun H, Thom E, Wadstein J \& Gudmundsen O (2000) Conjugated linoleic acid (CLA) reduces body fat in overweight and obese humans. $J$ Nutr 130, 2943-2948.

25. Terpstra AHM (2001) Differences between humans and mice in efficacy of the body fat lowering effect of conjugated linoleic acid: role of metabolic rate. J Nutr 131, 2067-2068.

26. Badinga L, Selberg KT, Dinges AC, Comer CW \& Miles RD (2003) Dietary conjugated linoleic acid alters hepatic lipid content and fatty acid composition in broiler chickens. Poult Sci $\mathbf{8 2}$, $111-116$

27. Talbot DA, Duchamp C, Rey B, Hanuise N, Rouanet JL, Sibille B \& Brand MD (2004) Uncoupling protein and ATP/ADP carrier increase mitochondrial proton conductance after cold adaptation of king penguins. $J$ Physiol 558, 123-135.

28. Lee KN, Storkson JM \& Pariza MW (1995) Dietary conjugated linoleic acid changes fatty acid composition in different tissues by decreasing mono-unsaturated fatty acids. IFT Annual Meeting. Book of Abstracts 183.

29. Choi Y, Kim Y, Han Y, Park Y, Pariza MW \& Ntambi JM (2000) The trans-10, cis-12 isomer of conjugated linoleic acid downregulates stearoyl-CoA desaturase 1 gene expression in 3T3-L1 adipocytes. J Nutr 130, 1920-1924.

30. Szymczyk B, Pisulewski PM, Szczurek W \& Hanczakowski P (2001) Effects of conjugated linoleic acid on growth performance, feed conversion efficiency, and subsequent carcass quality in broiler chickens. Br J Nutr 85, 465-473.

31. Sisk MB, Hausman DB, Martin RJ \& Azain MJ (2001) Dietary conjugated linoleic acid reduces adiposity in lean but not in obese Zucker rats. J Nutr 131, 1668-1674.

32. Du M, Ahn DU, Nam KC \& Sell JL (2001) Volatile profiles and lipid oxidation of irradiated cooked chicken meat from laying hens fed diets containing conjugated linoleic acid. Poult Sci 80, 235-241.

33. Watkins BA, Feng S, Strom AK, DeVitt AA, Yu L \& Li Y (2003) Conjugated linoleic acids alter the fatty acid composition and physical properties of egg yolk and albumin. J Agric Food Chem 51, 6870-6876.

34. Muma E, Palander S, Nasi M, Pfeiffer AM, Keller T \& Griinari JM (2006) Modulation of conjugated linoleic acid-induced loss of chicken eggs hatchability by dietary soybean oil. Poult Sci 85, 712-720.

35. Stangle GI (2000) Conjugated linoleic acids exhibit a strong fat-to-lean partitioning effect, reduce serum VLDL lipids and redistribute tissue lipids in food-restricted rats. J Nutr Biochem 130, $1140-1146$.

36. Lee KN, Pariza MW \& Ntambi JM (1998) Conjugated linoleic acid decreases hepatic steroyl-CoA desaturase mRNA expression. Biochem Biophys Res Commun 248, 817-821.

37. Li Y \& Watkins BA (1998) Conjugated linoleic acids alter bone fatty acid composition and reduce ex vivo prostaglandins $E_{2}$ 
biosynthesis in rats fed $\mathrm{n}-6$ or $\mathrm{n}-3$ fatty acids. Lipids 33, 417-425.

38. Bretillon L, Chardigny JM, Gregorie S, Berdeaux O \& Sebedio JL (1999) Effects of conjugated linoleic acid isomers on the hepatic microsomal desaturation activities in vitro. Lipids 34, 965-969.

39. Belury MA \& Kempa-Steczko A (1997) Conjugated linoleic acid modulates hepatic lipid composition in mice. Lipids 32, 197-204.

40. Park Y, Storkson JM, Ntambi JM, Cook ME, Sih CJ \& Pariza MW (2000) Inhibition of hepatic stearoyl-CoA desaturase activity by trans-10, cis-12 conjugated linoleic acid and its derivatives. Biochim Biophys Acta 1486, 285-292.

41. Choi Y, Park Y, Pariza MW \& Ntambi JM (2001) Regulation of stearoyl-CoA desaturase activity by the trans-10, cis-12 isomer of conjugated linoleic acid in HepG2 cells. Biochem Biophys Res Commun 284, 689-693.

42. Eder K, Slomma N \& Becker K (2002) Trans-10,cis-12 conjugated linoleic acid inhibits the desaturation of linoleic acid and $\alpha$-linoleic acid and stimulates the synthesis of prostaglandins in HepG2 cells. J Nutr 132, 1115-1121.

43. Banni S, Angioni E, Casu V, Melis M, Carta G, Corongiu FP, Thompson H \& Ip C (1997) Decrease in linoleic acid metabolites as a potential mechanism in cancer risk reduction by conjugated linoleic acid. Carcinogenesis 20, 1019-1024.

44. Poulos SP, Sisk M, Hausman DB, Azain MJ \& Hausman GJ (2001) Pre- and post-natal dietary conjugated linoleic acid alters adipose tissue development, body weight gain and body composition in Sprague-Dawley rats. J Nutr 131, 2722-2731.
45. Kavanaugh CJ, Liu KL \& Belury MA (1999) Effect of dietary conjugated linoleic acid on phorbol ester-induced PGE2 production and hyperplasia in mouse epidermis. Nutr Cancer 33, $132-138$

46. Banni S, Carta G, Angioni E, Murru E, Scanu P, Melis MP, Bauman DE, Fisher SM \& Ip C (2001) Distribution of conjugated linoleic acid and metabolites in different lipid fraction in the rat liver. J Lipid Res 42, 1056-1061.

47. Li Y, Seifert MF, Ney DM, Grahn M, Grant AL, Allen KG \& Watkins BA (1999) Dietary conjugated linoleic acids alter serum IGF-I and IGF binding protein concentrations and reduce bone formation in rats fed $\mathrm{n}-6$ or $\mathrm{n}-3$ fatty acids. $J$ Bone Miner Res 14, 1153-1162.

48. Moya-Camarena SY, Van den Heuvel JP \& Belury MA (1999) Conjugated linoleic acid activates peroxisome proliferator-activated receptor $\alpha$ and $\beta$ subtypes but does not induce hepatic peroxisome proliferation in Sprague-Dawley rats. Biochim Biophys Acta 1436, 331-342.

49. Petrik MBH, McEntee MF, Johnson BT, Obukowicz MG \& Whelan J (2000) Highly unsaturated (n-3) fatty acids, but not $\alpha$ conjugated linoleic or $\gamma$-linolenic acids, reduce tumorigenesis in Apc(Min/+) mice. $J$ Nutr 130, 2434-2443.

50. Javadi M, Beynen AC, Hovenier R, Lankhorst $Æ$, Lemmens AG, Terpstra AHM \& Geelen MJH (2004) Prolonged feeding of mice with conjugated linoleic acid increases hepatic fatty acid synthesis relative to oxidation. $J$ Nutr Biochem 15, 680-687. 